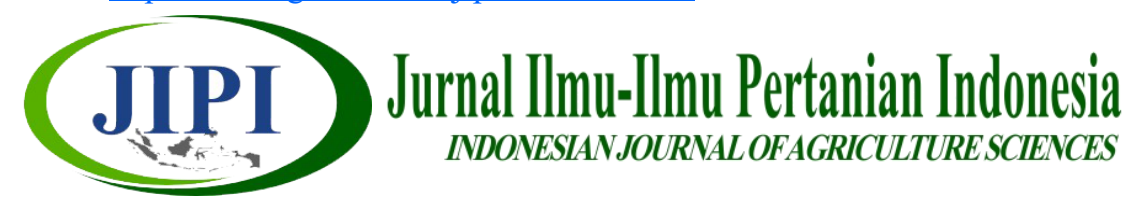

\title{
PEMBERIAN DUA JENIS AMELIORAN TERHADAP PERFORMA TANAMAN OKRA (Abelmoschus esculentus) PADA ULTISOL
}

\author{
Cintya Ramadhani ${ }^{1}$, Sumardi ${ }^{*}$, Bambang Gonggo Murcitro ${ }^{2}$ \\ ${ }^{1}$ Program Studi Agroekoteknologi, Fakultas Pertanian Universitas Bengkulu \\ ${ }^{2}$ Program Studi Ilmu Tanah, Fakultas Pertanian Universitas Bengkulu \\ *Corresponding Author : sumardi@unib.ac.id
}

\begin{abstract}
[APLICATION OF TWO AMELIORANT TYPES OF OKRA PLANT PERFORMANCE (Abelmoschus esculentus) IN ULTISOL]. This study aims to determine the dosage of dolomite lime and the type of organic fertilizer that can produce the highest performance of okra plants. This research is an experiment that was compiled based on factorial CRD. The first factor is dolomite dosage, which consists of three levels; 1.11 tons/ha, 1.76 tons/ha, and 2.40 tons/ha. The second factor is the type of organic fertilizer consisting of three types; chicken manure, cow manure, and palm oil solid organic fertilizer. The results showed that the dolomite dose of 2.4 tons/ha produced the highest number of fruits/plants (5.8 fruits) and the heaviest fruit/plant weights $(82.1 \mathrm{~g})$. Chicken manure and cow manure produce the highest plant height performance okra $(29.8 \mathrm{~cm}-31.6 \mathrm{~cm})$, the largest stem diameter $(72.8 \mathrm{~mm}-73.8 \mathrm{~mm})$, the highest number of branches (3 stems), the number most fruits / plants (5 - 7) and the largest fruit / plant weight (72.4 $\mathrm{g}-81.4 \mathrm{~g}$ ). The interaction between dolomite dosage and organic fertilizer did not significantly affect the performance of okra plants.
\end{abstract}

Keyword: okra,dolomite, organic fertilizer, Ultisol

\begin{abstract}
ABSTRAK
Penelitian ini bertujuan untuk menentukan dosis kapur dolomit dan jenis pupuk organik yang mampu menghasilkan peforma tanaman okra tertinggi. Penelitian ini merupakan percobaan yang disusun atas dasar RAL faktorial. Faktor pertama yaitu dosis dolomit yang terdiri atas tiga taraf; 1,11 ton/ha, 1,76 ton/ha dan 2,40 ton/ha. Faktor kedua yaitu jenis pupuk organik terdiri atas tiga jenis ; pupuk kandang ayam, pupuk kandang sapi dan pupuk organik padat tandan kosong kelapa sawit. Hasil penelitian menunjukkan bahwa dosis dolomit 2,4 ton/ha menghasilkan jumlah buah/tanaman terbanyak $(5,8$ buah) dan bobot buah/tanaman terberat $(82,1 \mathrm{~g})$. Pupuk kandang ayam dan pupuk kandang sapi menghasilkan peforma tanaman okra tinggi tanaman tertinggi $(29,8 \mathrm{~cm}-31,6 \mathrm{~cm})$, diameter batang terbesar (72,8 mm $-73,8 \mathrm{~mm}$ ), jumlah cabang terbanyak (3 tangkai), jumlah buah/tanaman terbanyak (5 buah -7 buah) dan bobot buah/tanaman terbesar $(72,4 \mathrm{~g}-81,4 \mathrm{~g})$. Interaksi yang terjadi antara dosis dolomit dan pupuk organik berpengaruh tidak nyata terhadap performa tanaman okra.
\end{abstract}

Kata kunci: okra, dolomit, pupuk kandang, Ultisol 


\section{PENDAHULUAN}

Okra (Abelmoschus esculentus) merupakan salah satu jenis sayuran yang berasal dari benua Afrika. Tanaman ini dikenal sebagai ladies fingers yang memiliki kandungan serat pangan dan vitamin yang tinggi. Pada $100 \mathrm{~g}$ bahan Okra mengandung 90,7 g air, $57 \mathrm{mg} \mathrm{Mg}$, $81 \mathrm{mg} \mathrm{Ca}, 63 \mathrm{mg}$ P, $303 \mathrm{mg} \mathrm{K}, 8 \mathrm{~g} \mathrm{Na}, 21,1 \mathrm{mg}$ vitamin $\mathrm{C}, 0,36 \mathrm{mg}$ vitamin $\mathrm{E}$ dan $53 \mathrm{mg}$ vitamin $\mathrm{K}$ (Roy et al., 2014). Selain sebagai sayuran tanaman ini juga dikonsumsi sebagai obat karena memiliki banyak manfaat kesehatan (Singh et al., 2014) salah satunya dapat meningkatkan aktivitas memori otak serta membantu penderita alzhemeirs (Kumar et al., 2013). Berdasarkan kandungan dan khasiatnya Okra memiliki prospek bagus untuk dikembangkan di Indonesia termasuk di daerah Bengkulu.

Bengkulu mempunyai sebaran tanah masam termasuk jenis ultisol sekitar $89,87 \%$ dari sebaran tanah sub optimal (Mulyani \& Sarwani, 2013). Berkurangnya lahan potensial pertanian akibat konversi lahan membuat pemanfaatan tanah sub optimal menjadi salah satu solusi. Ultisol umumnya dicirikan dengan warna kuning kecokelatan hingga merah (Prasetyo \& Suriadikarta, 2006). Tanah jenis ini memiliki beberapa kelemahan dalam penggunaannya sebagai lahan pertanian, seperti $\mathrm{pH}$ tanah dan kandungan bahan organik yang rendah (Sujana, 2015), serta memiliki nilai kapasitas tukar kation (KTK) rendah (Nariratih et al., 2013) dan kejenuhan Al tanah yang tinggi (Syahputra et al., 2015). Peningkatan kejenuhan Al bernilai negatif pada produksi kakao, atau dengan kata lain semakin meningkat kejenuhan Al maka menjadi berkurang produksi kakao (Liyanda et al., 2012). Kemasaman tanah juga membuat produksi kakao yang merupakan tanaman satu famili dengan okra semakin rendah. Okra dapat tumbuh subur pada pH tanah 6- 7 (Drost \& Ernst, 2012). Selain itu kandungan $\mathrm{Ca}$ pada ultisol tergolong rendah padahal $\mathrm{Ca}$ beperan penting dalam pembentukkan akar pada tanaman Okra (Kashif et al., 2012).

Selama ini metode yang digunakan untuk mengatasi kelemahan ultisol di antaranya pemberian amelioran seperti kapur, pupuk dan pengelolaan bahan organik. Pemberian amelioran kapur pertanian dapat meningkatkan $\mathrm{pH}$ tanah, dan menurunkan kelarutan Al (Yenni, 2012), serta dapat meningkatkan KTK tanah (Syaputra et al., 2015). Kapur yang umum digunakan sebagai bahan amelioran adalah dolomit dan kaptan. Penggunaan dolomit sebagai amelioran memiliki beberapa kelebihan dibandingkan kaptan yaitu harga beli relatif lebih murah, serta memiliki kandungan magnesium $(\mathrm{Mg})$ dan Kalsium (Ca) yang berfungsi sebagai penambah unsur hara. Unsur Mg berperanan penting untuk transportasi P pada tanaman (Turang \& Wowiling, 2015). Salah satu metode yang juga sering digunakan untuk mengatasi kelemahan ultisol adalah pemupukan. Terdapat dua jenis pupuk yang digunakan yaitu pupuk organik dan pupuk anorganik (Sutanto, 2002).

Jenis pupuk yang selama ini sering digunakan adalah pupuk anorganik, hal ini karena kandungan haranya cepat tersedia bagi tanaman namun penggunaannya secara terus menerus memiliki kelemahan. Kelemahan pupuk anorganik yaitu dapat merusak struktur tanah, menurunkan $\mathrm{pH}$ tanah dan menurunkan aktivitas mikroorganisme tanah (Savci, 2012). Penggunaan pupuk organik memiliki beberapa kelebihan dibandingkan anorganik seperti dapat memperbaiki sifat fisik, kimia, dan biologi tanah. Pupuk ini berperan dalam penyediaan unsur hara makro dan mikro, meningkatkan KTK tanah, memperbaiki struktur tanah, mengurangi fluktuasi suhu tanah serta sebagai sumber energi bagi mikro dan meso fauna tanah (Hartatik \& Setyorini, 2012). Beberapa jenis pupuk organik yang umum digunakan adalah pupuk kandang dan pupuk kompos yang berasal dari tumbuhan. Pupuk kandang ayam memiliki kandungan hara makro lebih tinggi dibanding pupuk kandang sapi $\mathrm{N}(1,4 \%), \mathrm{P}_{2} \mathrm{O}_{5}(1,34 \%)$ dan $\mathrm{K}_{2} \mathrm{O}(2,3 \%)$ sedangkan pupuk kandang sapi mengandung $\mathrm{N}(0,46 \%)$, $\mathrm{P}_{2} \mathrm{O}_{5}(0,83 \%)$ dan $\mathrm{K}_{2} \mathrm{O}(0,3 \%)$ (Maryam et al., 2015).

Beberapa penelitian mengenai tanaman okra yang telah dilakukan sebelumnya adalah pengaruh pupuk kandang dengan NPK (Mahendra, 2018) juga pengaruh kombinasi pupuk kompos dan NPK pada tanaman okra (Yuliartini et al., 2018). Penggunaan pupuk organik secara nyata mampu meningkatkan parameter pertumbuhan maupun hasil tanaman. Akhir-akhir ini mulai dikembangkan pupuk organik yang berasal dari tandan kosong kelapa sawit yang merupakan limbah terbesar di perkebunan kelapa sawit. Data Direktorat Perkebunan tahun 2015 menunjukkan bahwa produksi sawit sebesar 6.214 .003 ton menghasilkan limbah berupa tandan kosong mencapai $21 \%$ atau sekitar 1.304.940,63 ton. Pupuk organik padat tandan kosong kelapa sawit mengandung N (1,25\%), $\mathrm{P}_{2} \mathrm{O}_{5}(3,70 \%)$ dan $\mathrm{K}_{2} \mathrm{O}(0,89 \%)$ (Sofyan, 2017). Pemanfaatan tandan kosong kelapa sawit sebagai pupuk diharapkan dapat mengurangi limbah yang ada dan memperbaiki kualitas tanah (Simbolon et al., 2018). Kombinasi kapur pertanian dan pupuk organik diyakini mampu meningkatkan ketersediaan unsur hara selama pertumbuhan vegetatif maupun generatif tanaman.

Penelitian ini bertujuan untuk menentukan dosis kapur dolomit dan jenis pupuk organik yang mampu menghasilkan peforma tanaman okra tertinggi.

\section{METODE PENELITIAN}

Penelitian dilaksanakan pada bulan Desember 2018 sampai Maret 2019 dengan polybag yang di tempatkan di lahan Kandang Limun Kota Bengkulu. 
Bahan-bahan yang digunakan dalam penelitian ini adalalah benih tanaman okra, kapur dolomit, pupuk kandang ayam, pupuk kandang sapi dan pupuk organik padat tandan kosong kelapa sawit. Alat-alat yang digunakan dalam penelitian ini adalah meteran, polybag ukuran $10 \mathrm{~kg}$ tanah $(50 \mathrm{~cm} \times 50 \mathrm{~cm})$, cangkul, ayakan, waring jaring, label, timbangan, gembor dan alat tulis. Penelitian ini merupakan percobaan dengan dua faktor yang disusun atas dasar Rancangan Acak Lengkap (RAL) faktorial dengan 3 ulangan, yaitu : dosis dolomit (d) sebagai faktor pertama yang terdiri atas 3 taraf dosis, yaitu: 1,11 ton/ha $\left(\mathrm{d}_{1}\right) ; 1,76$ ton/ha $\left(\mathrm{d}_{2}\right)$ dan 2,40 ton/ha $\left(d_{3}\right)$. Dosis kapur yang digunakan sesuai kebutuhan kapur dolomit yang didasarkan atas beberapa tingkat kejenuhan Al. Faktor kedua yang terdiri atas 3 jenis pupuk organik, yaitu pupuk kandang ayam $\left(\mathrm{o}_{1}\right)$; pupuk kandang sapi $\left(\mathrm{o}_{2}\right)$; dan pupuk organik padat tandan kosong kelapa sawit $\left(\mathrm{o}_{3}\right)$. Dosis yang digunakan untuk setiap jenis bahan organik adalah subsitusi $\mathrm{N}$ setara dosis urea yang dibutuhkan yaitu $200 \mathrm{~kg} / \mathrm{ha}$. Dari kedua perlakuan di atas diperoleh $9 \mathrm{kom}-$ binasi perlakuan, dan terdapat perlakuan kontrol sebagai pembanding yang masing-masing diulang 3 kali setiap perlakuan, dalam setiap ulangan terdapat 2 polybag sehinga diperoleh 60 polybag. Benih yang digunakan dalam penelitian ini adalah benih Okra Naila IPB. Analisis tanah dilakukan sebelum penanaman untuk kadar $\mathrm{pH}, \mathrm{N}$, kation dapat tukar $(\mathrm{Ca}, \mathrm{Mg}, \mathrm{K}, \mathrm{Na}), \mathrm{Al}-\mathrm{dd}$ dan H-dd. Selain sifat-sifat kimia tanah tersebut juga dilakukan pengukuran sifat fisika tanah yaitu BV tanah dengan metode ring sampel. Tanah penelitian diayak dengan mata ayakan $2 \mathrm{~mm}$. Tanah yang lolos mata ayakan $2 \mathrm{~mm}$ digunakan sebagai media tanam. Kapasitas lapang tanah dihitung dengan cara volume air yang diberikan dikurangi volume air yang menetes keluar polybag. Kapasitas lapang tanah yang didapat sebesar 1,5 L digunakan sebagai dasar penyiraman setiap hari saat tidak terjadi hujan. Amelioran berupa dolomit yang diayak dengan ayakan 100 mesh dan dikompositkan dengan tanah sesuai perlakuan dengan memperhatikan BV tanah yang telah dihitung. Tanah yang telah dicampur dolomit disiram menggunakan air setiap hari sesuai dengan kapasitas lapang tanah selama 2 minggu sebelum tanam. Pupuk kandang ayam dan pupuk kandang sapi yang digunakan dikering anginkan kemudian diayak menggunakan ayakan 10 mesh (2 $\mathrm{mm})$. Pupuk anorganik yang diberikan berupa pupuk dasar urea, SP-36 dan KCl. Dosis urea yang dianjurkan 200 kg/ha, SP-36 100 kg/ha dan KCl 100 kg/ha. Pemberian dosis pupuk anorganik untuk penelitian ini adalah $1 / 2$ dari dosis anjuran sebagai pupuk dasar. Perhitungan kebutuhan Urea, SP-36 dan KCl. Penanaman diawali dengan proses perendaman benih selama 6 jam di dalam air agar lebih cepat berkecambah. Setelah itu, benih ditanam dalam polybag dengan jarak antar tanaman $50 \mathrm{~cm}$ x $50 \mathrm{~cm}$ (Raditya et al., 2017). Proses pemanenan dilakukan pada umur 46 hst dengan ciri-ciri buah okra memiliki panjang standar yang disukai konsumen yakni $6,5 \mathrm{~cm}-9 \mathrm{~cm}$ (Kirana et al., 2017). Pemanenan dilakukan dengan interval 2 hari sekali sebanyak 10 kali panen. Data yang dikumpulkan dianalisis secara statistik dengan Analisis Keragaman, sedangkan perbandingan rata-rata antar perlakuan melalui BNT pada taraf 5\% (Gomez \& Gomez, 1984).

\section{HASIL DAN PEMBAHASAN}

Karakteristik tanah yang digunakan saat penelitian memiliki pH 5,01 (masam), kandungan C-organik tergolong rendah sebesar $1,48 \%$, kandungan $\mathrm{N}$-total yang rendah yaitu sebesar $0,10 \%$, kandungan $\mathrm{K}$-dd yang rendah sebesar $0,21 \mathrm{cmol}(+) \mathrm{kg}^{-1}$, kandungan Al-dd dan $\mathrm{P}_{2} \mathrm{O}_{5}$ yang sangat rendah yaitu $1,59 \mathrm{me} / 100 \mathrm{~g}$ dan $7 \mathrm{ppm}$. Jika dilihat dari data tersebut, maka tanah yang digunakan pada penelitian ini tergolong dalam kriteria tanah yang kurang subur (BPPP, 2005).

Selama penelitian berlangsung total curah hujan $602 \mathrm{~mm}$. Total curah hujan ini mencukupi kebutuhan air selama pertumbuhan okra yaitu sekitar 584,21 $\mathrm{mm}$ (Grillo, 2018). Okra tidak memerlukan curah hujan yang tinggi tetapi jika terlalu kering tanaman memerlukan irigasi (Winch, 2006). Suhu rata-rata udara selama penelitian berlangsung sekitar $27{ }^{\circ} \mathrm{C}$ $27,2{ }^{\circ} \mathrm{C}$. Suhu tersebut optimum bagi pertumbuhan yang berkisar antara $26,9{ }^{\circ} \mathrm{C}-30{ }^{\circ} \mathrm{C}$ (Dhankhar et al., 2012). Pada saat okra berumur 40 hst daun okra diserang oleh hama semut, belalang, ulat dan kepik. Tindakan pengendalian dilakukan dengan menyemprotkan insektisida kontak berbahan aktif Sipermetrin dengan dosis anjuran 1,5 mL/L. Setelah dilakukan penyemprotan, tingkat kerusakan akibat serangan hama dapat ditekan. Panen okra dilakukan pada umur 46 hst ditandai dengan adanya buah okra yang sudah mencapai panjang buah $6,5 \mathrm{~cm}$.

Hasil analisis varian atau uji F 5\% menunjukkan interaksi yang tidak nyata $(\mathrm{P}>0,05)$ antar perlakuan. Pemberian dolomit secara mandiri juga berpengaruh tidak nyata pada semua variabel pertumbuhan sedangkan pada variabel hasil berpengaruh nyata $(\mathrm{P} \leq 0,05)$ pada jumlah buah/ tanaman dan bobot buah/tanaman. Pemberian jenis pupuk organik secara mandiri berpengaruh nyata pada variabel tinggi tanaman umur 40 hst dan 60 hst, diameter 20 hst, jumlah cabang, jumlah buah/tanaman, dan bobot buah/tanaman.Hasil penelitian pertumbuhan dan hasil kacang tanah pemberian dolomit dan pupuk organik menunjukkan interaksi yang terjadi juga tidak nyata (Syahrizal et al., 2014), begitu juga dengan tanaman kedelai (Saputro et al., 2017). Seperti dijelaskan oleh Tenaya (2015) saat interaksi 
berpengaruh tidak nyata, maka faktor-faktor perlakuan tersebut bertindak bebas atau berpengaruh secara mandiri. Pertumbuhan dan hasil tanaman okra tanpa pemberian amelioran lebih rendah $20 \%$ untuk tinggi tanaman dan 57,6\% untuk jumlah buah dibandingkan yang diberikan amelioran dolomit dan pupuk organik. Pertumbuhan dan hasil tanaman okra selain dipengaruhi oleh faktor genetik juga dipengaruhi oleh faktor lingkungan. Pada lingkungan yang optimum, tanaman dapat menyelesaikan siklus hidupnya secara lengkap serta dapat mengekspresikan program genetiknya secara utuh (Sitompul \& Guritno, 1995). Tanah yang digunakan pada penelitian ini termasuk jenis tanah yang kurang subur. Pada perlakuan kontrol tanaman hanya memanfaatkan unsur hara yang ada pada tanah tanpa mendapatkan unsur hara tambahan. Kebutuhan unsur hara pada tanaman sendiri harus terpenuhi agar tanaman dapat tumbuh normal (Turang \& Wowiling, 2015).

Pemberian dolomit pada taraf yang berbeda direspon sama oleh setiap jenis pupuk organik, hal ini karena pupuk organik yang digunakan saat penelitian sudah matang atau bisa dimanfaatkan langsung oleh tanaman. Ciri-ciri pupuk kandang yang sudah matang yaitu remah dan tidak berbau (Trivana \& Pradhana, 2017), sedangkan pupuk organik padat tandan kosong kelapa sawit memiliki $\mathrm{C} / \mathrm{N}$ rasio 19,74. Oleh karena itu, pemberian dolomit berpengaruh tidak nyata terhadap penyerapan pupuk organik sehingga interaksi yang terjadi tidak nyata. Secara umum kombinasi dosis dolomit 2,4 ton/ha dengan pupuk kandang ayam memberikan hasil tertinggi pada awal pertumbuhan tinggi tanaman $13 \mathrm{~cm}$, jumlah buah/tanaman 7,16, bobot buah/tanaman 94,42 g serta menurunkan kemasaman paling tinggi hingga $\mathrm{pH} 6,82$. Namun demikian hasil jumlah buah/tanaman pada penelitian ini lebih rendah 70,6\% jika dibandingkan dengan deskripsi varietas. Hal ini karena unsur hara yang disediakan oleh amelioran pupuk organik tersedia secara perlahanlahan (Sentana, 2010). Selain itu pada saat umur tanaman 40 hst tanaman terserang hama semut, ulat dan belalang yang membuat daun tanaman okra yang terserang menjadi berlubang, oleh karena itu fotosintesis yang terjadi dalam hal ini penerimaan cahaya diduga tidak optimum sehingga mempengaruhi hasil fotosintat yang akan didistribusikan pada organ lain termasuk untuk hasil tanaman (Zakarriya, 2016). Hasil penelitian Adeniyi \& Ayandiji (2011) menunjukkan tahap awal pembungaan dan pembuahan merupakan periode kritis pengendalian hama.

Dolomit merupakan salah satu jenis kapur pertanian yang sering digunakan untuk meningkatkan kemasaman tanah serta membantu meningkatkan produktivitas tanaman (Lamar, 1961). Pada semua variabel pertumbuhan tanaman okra, pemberian dosis dolomit memberikan pengaruh yang tidak nyata. Tinggi tanaman merupakan salah satu variabel pengamatan yang menandakan tanaman mengalami pertumbuhan terutama pada fase vegetatif. Napitupulu \& Winarto (2010) mengungkapkan bahwa unsur $\mathrm{N}$ berperan pada fase vegetatif yang mampu meningkatkan pertumbuhan seperti tinggi tanaman. Hasil penelitian Ispandi \& Munip (2005) menunjukkan bahwa pengapuran mampu meningkatkan serapan $\mathrm{P}$ dan $\mathrm{K}$ tetapi berpengaruh tidak nyata terhadap penyerapan $\mathrm{N}$ pada tanaman. Hal ini yang mungkin menyebabkan pemberian dolomit berpengaruh tidak nyata pada variabel vegetatif tanaman yaitu tinggi tanaman, diameter batang dan jumlah cabang. Penelitian Syahrizal et al. (2014) juga menunjukkan pemberian dolomit berpengaruh tidak nyata terhadap tinggi tanaman dan jumlah cabang kacang tanah.

Pemberian dosis dolomit pada variabel hasil berpengaruh tidak nyata pada rata-rata panjang buah dan rata-rata diameter buah namun berpengaruh nyata terhadap jumlah buah/tanaman dan bobot buah/tanaman namun yang disajikan pada Tabel 1.

Tabel 1. Pengaruh dosis dolomit terhadap hasil tanaman okra

\begin{tabular}{ccccc}
\hline $\begin{array}{c}\text { Dosis } \\
\text { dolomit } \\
\text { (ton/ha) }\end{array}$ & $\begin{array}{c}\text { Panjang } \\
\text { buah }(\mathrm{cm})\end{array}$ & $\begin{array}{c}\text { Diameter } \\
\text { buah }(\mathrm{cm})\end{array}$ & $\begin{array}{c}\text { Jumlah } \\
\text { buah/tanaman } \\
\text { (buah) }\end{array}$ & $\begin{array}{c}\text { Bobot } \\
\text { buah/tanaman }\end{array}$ \\
\hline 1,11 & 8,2 & 1,3 & $4,1 \mathrm{~b}$ & $61,3 \mathrm{~b}$ \\
\hline 1,76 & 8,5 & 1,3 & $5,5 \mathrm{ab}$ & $71,6 \mathrm{ab}$ \\
\hline 2,4 & 8,7 & 1,4 & $5,8 \mathrm{a}$ & $82,1 \mathrm{a}$ \\
\hline
\end{tabular}

Keterangan : Angka-angka yang diikuti oleh huruf yang sama pada kolom yang sama berbeda tidak nyata pada BNT $5 \%$

Pemberian tiga taraf dosis dolomit berpengaruh tidak nyata pada variabel rata-rata panjang buah dan rata-rata diameter buah. Hasil rata- rata pengukuran panjang buah tertinggi dan diameter terbesar dihasilkan oleh pemberian dolomit dengan dosis 2,4 ton/ha. Secara umum terlihat bahwa perlakuan dolomit dengan dosis 2,4 ton/ha memiliki nilai rata-rata pengamatan lebih tinggi dibanding dosis 1,11 ton/ha namun berbeda tidak nyata dengan dosis 1,76 ton/ha. Hasil penelitian menunjukkan bahwa dosis dolomit 2,4 ton/ha mampu menghasilkan jumlah buah dan bobot buah/tanaman lebih tinggi dibanding dosis 1,11 ton/ha.

Jumlah buah merupakan salah satu variabel hasil yang penting. Pemberian kapur dolomit ke dalam tanah terbukti meningkatkan $\mathrm{pH}$ tanah. Pemberian dosis dolomit 1,11 ton/ha mampu meningkatkan $\mathrm{pH}$ tanah sebesar 0,61 dari $\mathrm{pH}$ awal 5,01 menjadi 5,62, sedangkan dosis dolomit 1,76 ton/ha meningkatkan $\mathrm{pH}$ tanah sebesar 0,73 dan peningkatan $\mathrm{pH}$ tertinggi yaitu pada pemberian dosis dolomit 2,4 ton/ha sebesar 0,83 . Semakin tinggi peningkatan $\mathrm{pH}$ makin banyak dolomit yang dibutuhkan (Dariah et al., 2015). Pening- 
katan ini terjadi disebabkan oleh adanya gugus ionion hidroksil yang mengikat kation-kation asam $(\mathrm{H}$ dan $\mathrm{Al})$ pada koloid tanah menjadi inaktif, sehingga $\mathrm{pH}$ meningkat. Hasil penelitian Koesrini et al. (2015) menunjukkan pengapuran secara nyata meningkatkan $\mathrm{pH}$ tanah dan menurunkan kejenuhan Al. Menurut Sudaryono (2009) umumnya tanaman dapat tumbuh baik dikisaran $\mathrm{pH}$ 5,5-7 karena pada $\mathrm{pH}$ di bawah 5,5 unsur $\mathrm{P}$ akan diikat oleh $\mathrm{Fe}$ dan $\mathrm{Al}$ sehingga tidak tersedia bagi tanaman sedangkan pada $\mathrm{pH}$ di atas 7,0 unsur $\mathrm{P}$ akan bereaksi dengan $\mathrm{Ca}$ dan $\mathrm{Mg}$. Unsur $\mathrm{P}$ merupakan salah satu unsur hara esensial bagi tanaman. Artinya unsur $\mathrm{P}$ tidak dapat digantikan fungsinya oleh unsur lain, sehingga tanaman harus mendapatkan unsur hara $\mathrm{P}$ secara cukup untuk pertumbuhannya. Kebutuhan unsur hara P harus tercukupi sejak awal pertumbuhan agar produksi tanaman optimal (Grant et al., 2005). Selanjutnya penelitian Adam et al. (2013) menunjukkan pupuk $\mathrm{P}$ berpengaruh nyata terhadap variabel jumlah buah, panjang buah dan bobot buah tanaman timun. Bertambahnya jumlah buah berkorelasi positif dengan bobot buah/tanaman $(\mathrm{r}=0,82 *)$. Semakin banyak jumlah buah yang dihasilkan per tanaman maka bobot buah/tanaman nyata bertambah.

Bobot buah/tanaman memberikan hasil yang lebih baik pada pemberian dosis 2,40 ton/ha dibandingkan dosis 1,11 ton/ha namun berbeda tidak nyata dengan pemberian dosis 1,76 ton/ha. Penelitian Kasmawardani et al. (2017) menunjukkan pemberian dolomit berpengaruh nyata terhadap bobot basah bunga kol. Pemberian dolomit secara nyata mampu meningkatkan serapan K (Ispandi \& Munip, 2005). K merupakan unsur hara yang berperan penting terhadap translokasi hasil fotosintat termasuk pada pembesaran buah. Pemberian K mampu meningkatkan bobot buah tanaman cabai (Nurwanto \& Sulistyaningsih, 2017).

Pupuk organik merupakan sumber nutrisi alami yang dapat meningkatkan produktivitas tanaman serta meningkatkan kesuburan tanah dalam jangka panjang (Singh, 2012). Pemberian tiga jenis pupuk organik secara mandiri berpengaruh nyata pada semua variabel pertumbuhan (Tabel 2).

Tabel 2. Pengaruh pupuk organik terhadap pertumbuhan tanaman okra

\begin{tabular}{l|c|c|c|c|c}
\hline $\begin{array}{l}\text { Jenis pupuk } \\
\text { organik }\end{array}$ & $\begin{array}{c}\text { Tinggi tanaman } \\
40 \mathrm{hst}(\mathrm{cm})\end{array}$ & $\begin{array}{c}\text { Tinggi } \\
\text { tanaman } 60 \\
\text { hst (cm) }\end{array}$ & $\begin{array}{c}\text { Diameter } \\
\text { batang 20 } \\
\text { hst (mm) }\end{array}$ & $\begin{array}{c}\text { Diameter batang } \\
40 \text { hst (mm) }\end{array}$ & $\begin{array}{c}\text { Jumlah } \\
\text { cabang } \\
\text { (tangkai) }\end{array}$ \\
\hline Pukan ayam & $31,6 \mathrm{a}$ & $73,8 \mathrm{a}$ & $4,0 \mathrm{a}$ & $12,4 \mathrm{a}$ & $3,2 \mathrm{a}$ \\
\hline Pukan sapi & $29,8 \mathrm{ab}$ & $72,8 \mathrm{a}$ & $3,3 \mathrm{ab}$ & $11,4 \mathrm{a}$ & $2,9 \mathrm{a}$ \\
\hline $\begin{array}{l}\text { Pupuk organik } \\
\text { padat TKKS }\end{array}$ & $26,2 \mathrm{~b}$ & $62,7 \mathrm{~b}$ & $2,7 \mathrm{~b}$ & $9,1 \mathrm{~b}$ & $1,9 \mathrm{~b}$ \\
\hline
\end{tabular}

Keterangan : Angka-angka yang diiluti oleh huruf yang sama pada kolom yang sama berbeda tidak nyata pada BNT $5 \%$
Saat umur tanaman 40 hst tanaman okra yang diberi pupuk kandang ayam menghasilkan pertumbuhan tinggi tanaman yang lebih baik dibandingkan yang diberi pupuk organik tandan kosong kelapa sawit namun berbeda tidak nyata dengan yang diberi pupuk kandang sapi dan setelah umur tanaman 60 hst hari setelah tanam pemberian pupuk kandang ayam dan pupuk kandang sapi memberikan pertumbuhan tinggi tanaman yang lebih baik dibandingkan pupuk organik padat tandan kosong kelapa sawit. Pupuk kandang ayam mampu meningkatkan tinggi tanaman, jumlah buah/tanaman serta bobot buah/tanaman (Barus et al., 2018). Hal ini karena pelapukan bahan organik yang bersumber dari tandan kosong kelapa sawit memerlukan waktu relatif lebih lama dibanding pupuk kandang. Komponen penyusun tandan kosong kelapa sawit kaya akan unsur karbon yaitu selulosa 34\% (Dewanti, 2018) serta 16,42\% kandungan lignin (Simatupang et al., 2012) sehingga memerlukan waktu yang cukup lama untuk proses mineralisasi.

Diameter batang tanaman okra memiliki respon pertumbuhan yang lebih baik saat diberi pupuk kandang ayam daripada pupuk organik padat tandan kosong kelapa sawit namun berbeda tidak nyata dengan yang diberi pupuk kandang sapi saat umur tanaman 20 hst. Namun saat umur tanaman 40 hst pemberian pupuk kandang ayam dan pupuk kandang sapi memberikan pertumbuhan diameter batang okra yang lebih baik dibandingkan pupuk organik padat tandan kosong kelapa sawit. Perlakuan pupuk kandang ayam menghasilkan diameter batang yang lebih baik dibandingkan pupuk organik padat tandan kosong kelapa sawit karena kandungan $\mathrm{N}$ yang lebih tinggi. Kandungan $\mathrm{N}$ yang tinggi dapat membuat proses dekomposisi berlangsung lebih cepat. Unsur $\mathrm{N}$ sendiri merupakan unsur yang paling banyak dibutuhkan tanaman terutama pada fase vegetatif termasuk pertumbuhan diameter batang.

Jumlah cabang sebagai salah satu indikator penting pada pertumbuhan vegetatif tanaman. Kebutuhan hara makro dan mikro dalam jumlah optimal akan mendorong pertumbuhan tanaman menjadi lebih baik, tanaman memerlukan unsur hara yang optimum di awal pertumbuhannya yang bertujuan untuk memperlancar proses metabolisme pada fase vegetatif. Pemberian pupuk kandang ayam dan pupuk kandang sapi menghasilkan pertumbuhan cabang tanaman okra yang lebih baik dibanding pupuk organik padat tandan kosong kelapa sawit. Hal ini diduga karena unsur $\mathrm{N}$ pada pupuk kandang lebih mudah diserap tanaman dibandingkan pupuk organik tandan kosong kelapa sawit. Unsur ini berfungsi menyusun asam amino, asam nukleat dan klorofil pada tanaman sehingga dapat mempercepat petumbuhan tanaman seperti tinggi tanaman, diameter batang, jumlah anakan dan jumlah cabang (Rina, 
2015). Menurut Wartapa et al. (2009) jumlah cabang berkaitan erat hasil tanaman. Hal ini sesuai dengan hasil penelitian ini yang menunjukkan jumlah cabang terkait erat dengan jumlah buah pada tanaman okra ( $\mathrm{r}$ $=0,63 *)$. Perlakuan jenis pupuk organik berpengaruh tidak nyata pada variabel hasil rata-rata panjang buah dan rata-rata diameter buah namun berpengaruh nyata terhadap jumlah buah/tanaman dan bobot buah/tanaman (Tabel 3).

Tabel 3. Pengaruh pupuk organik terhadap hasil tanaman okra

\begin{tabular}{|l|c|c|c|c|}
\hline $\begin{array}{l}\text { Jenis pupuk } \\
\text { organik }\end{array}$ & $\begin{array}{c}\text { Panjang } \\
\text { buah }(\mathrm{cm})\end{array}$ & $\begin{array}{c}\text { Diameter } \\
\text { buah (mm) }\end{array}$ & $\begin{array}{c}\text { Jumlah } \\
\text { buah/tanaman } \\
\text { (buah) }\end{array}$ & $\begin{array}{c}\text { Bobot } \\
\text { buah/tanaman } \\
(\mathrm{g})\end{array}$ \\
\hline Pukan ayam & 8,6 & 1,4 & $6,6 \mathrm{a}$ & $81,4 \mathrm{a}$ \\
\hline Pukan sapi & 8,6 & 1,4 & $5,2 \mathrm{a}$ & $72,4 \mathrm{ab}$ \\
\hline $\begin{array}{l}\text { Pupuk organik } \\
\text { padat TKKS }\end{array}$ & 8,1 & 1,4 & $3,7 \mathrm{~b}$ & $61,2 \mathrm{~b}$ \\
\hline
\end{tabular}

Keterangan : Angka-angka yang diikuti oleh huruf yang sama pada kolom yang sama berbeda tidak nyata pada BNT $5 \%$

Respon jumlah buah/tanaman lebih baik pada pemberian pupuk kandang ayam dan pupuk kandang sapi dibandingkan pupuk organik tandan kosong kelapa sawit. Hal ini diduga karena pada masa vegetatif pertumbuhan tanaman okra yang diberikan pupuk kandang ayam dan pupuk kandang sapi lebih baik dibandingkan pupuk organik tandan kosong kelapa sawit sehingga menghasilkan jumlah buah yang lebih baik juga. Hasil penelitian Yuliartini et al. (2018) menunjukkan pemberian bahan organik mampu meningkatkan pertumbuhan vegetatif tanaman okra sehingga sehingga Bobot buah/tanaman sebagai bagian penting dari hasil tanaman okra memberikan respon yang lebih baik dengan pemberian pupuk kandang ayam dibandingkan pupuk organik padat tandan kosong kelapa sawit namun berbeda tidak nyata dengan pupuk kandang sapi. Salah satu unsur hara yang berpengaruh dalam pembesaran buah adalah unsur K. Pada perlakuan pupuk kandang ayam dan pupuk kandang sapi diduga unsur hara $\mathrm{K}$ lebih mudah diserap oleh tanaman hal ini karena pelapukan bahan yang berasal dari tandan kosong kelapa sawit membutuhkan waktu yang relatif lebih lama. Hal ini didukung oleh penelitian Afandi et al. (2015) yang menunjukkan pemberian pupuk kandang ayam dan pupuk kandang sapi berpengaruh nyata terhadap serapan $\mathrm{N}, \mathrm{P}$ dan $\mathrm{K}$ pada tanaman ubi jalar.

\section{KESIMPULAN}

Dosis dolomit 2,4 ton/ha menghasilkan jumlah buah/tanaman terbanyak $(5,8$ buah) dan bobot buah/ tanaman terberat $(82,1 \mathrm{~g})$.
Pupuk kandang ayam dan pupuk kandang sapi menghasilkan peforma tanaman okra tinggi tanaman tertinggi $(29,8 \mathrm{~cm}-31,6 \mathrm{~cm})$, diameter batang terbesar (72,8 mm - 73,8 mm), jumlah cabang terbanyak (3 tangkai), jumlah buah/tanaman terbanyak ( 5 buah -7 buah) dan bobot buah/tanaman terbesar $(72,4 \mathrm{~g}-81,4 \mathrm{~g})$.

Interaksi yang terjadi antara dosis dolomit dan pupuk organik berpengaruh tidak nyata terhadap performa tanaman okra.

\section{DAFTAR PUSTAKA}

Adam, S.Y., Bahua, M.I. \& F.S, Jamin, F.S. (2013). Pengaruh pupuk fosfor pada pertumbuhan dan produksi tanaman mentimun (Cucumis sativus l.). KIM Fakultas Ilmu-Ilmu Pertanian, 1(1), 124.

Adeniyi, Y.R. \& Ayandiji, A. (2011). An agroeconomic appraisal of the response of okra to leaf defoliation: Growth and marketable yield. African Journal of Food, Agriculture, $\mathrm{Nu}$ trition and Development, 11(3), 4867- 4879.

Afandi, F.N., Siswanto, B. \& Nuraini, Y. (2017). Pengaruh pemberian berbagai jenis bahan organik terhadap sifat kimia tanah pada pertumbuhan dan produksi tanaman ubi jalar di Entisol Ngrangkah

Pawon, Kediri. Jurnal Tanah dan Sumberdaya Lahan, 2(2), 237-244.

Badan Penelitian dan Pengembangan Pertanian. (2005). Analisis Kimia Tanah, Tanaman, Air dan Pupuk. Balai Penelitian Tanah, Departemen Pertanian, Bogor.

Barus, R.A.A., Hanum, C. \& Rosita, S. (2018). Respons pertumbuhan dan produksi dua varietas okra (Abelmoschus esculantus l. Moench) terhadap pemberian berbagai jenis pupuk organik. Jurnal Agroteknologi FP USU, 6(2), 253-258.

Dariah, A., Sutono, S., Nurida, N.L., Hartatik, W. \& Pratiwi, E. (2015). Pembenah tanah untuk meningkatkan produktivitas lahan pertanian. Jurnal Sumberdaya Lahan, 9(2), 67-84. DOI: http:// dx.doi.org/10.2018/jsdl.v9i2.6571.

Dewanti, D.P. (2018). Potensi selulosa dari limbah tandan kosong kelapa sawit untuk bahan baku bioplastik ramah lingkungan. Jurnal Teknologi Lingkungan, 19(1), 81-88. DOI: http:// dx.doi.org/10.29122/jtl.v19i1.2644.

Dhankhar, S.K., Deswal, D.P. \& Singh, S. (2012). Impact of weather variables on yield and yield attributes in Okra under different growing environments. Journal of Agrometeorology, 14(1). 54-56.

Direktorat Perkebunan. 2015). Statistik Perkebunan Indonesia (Tree Crop Estate Statistics of Indonesia 2015- 
2017). Departemen Pertanian, Ditjen Perkebunan, Jakarta.http://ditjenbun.pertanian.go.id/ tinymcpuk/gambar/file/statistik/2017/ KelapaSawit-2015-2017.pdf. 10 September 2018.

Drost, D. \& Ernst, T. (2012). Okra in the Garden. Paper 284. All Current Publications. https://digital commons. usu. edu lextension curall/284. 12 Desember 2018.

Gomez, K. A. \& Gomez, A.A. (1984). Statistical Procedures for Agricultural Research. John Wiley \& Sons, Inc. Diterjemahkan oleh. Syamsuddin, E. \& Baharsyah, J.S. (2010). Prosedur Statistik untuk Penelitian Pertanian. UI Press., Jakarta.

Grant, C., Bittman, S., Montreal, M., Plenchette, C. \& Morel, C. (2005). Soil and fertilizer phosphorus: Effects on plant $\mathrm{P}$ supply and mycorrhizal development. Canadian Journal of Plant Science, 85 (1): 3-14. DOI: https://10.4141/P03-182.

Grillo, O. (2018). Rediscovery of Land races as a Resource for the Future. E-book. https://books. google.co.id/books?id= 7 GiQDwAAQBAJ\& printsec $=$ frontcover $\# v=$ onepage $\& \& \&=$ false. DOI:http://dx.doi.org/10.5772/intechopen. 69576. 13 Mei 2019.

Hartatik, W. \& Setyorini, D. (2012). Pemanfaatan Pupuk Organik Untuk Meningkatkan Kesuburan Tanah dan Kualitas Tanaman. Balai Penelitian Tanah, Balitbangtan, Kementerian Pertanian, Bogor.

Ispandi, A. \& Munip, A. (2005). Efektifitas pengapuran terhadap serapan hara dan produksi beberapa klon ubikayu di lahan kering masam. Ilmu Pertanian, 12(2), 125-139.

Kasmawardani, Marlina, \& Mariana. (2017). Pengaruh pemberian pupuk organik dan kapur dolomit terhadap pertumbuhan dan hasil tanaman kol bunga (Brassica oleraceae Var. Botrytis L.). Agrotropika Hayati, 4(3), 152-164.

Kirana, R., Gaswanto, R. \& Hidayat, I.M. (2017). Budidaya dan Produksi Benih Okra. http:// hortikultura.litbang.pertanian.go.id/teknologidetail-93.html 12 Mei 2019.

Koesrini., Anwar, K. \& Berlian, E. (2015). Penggunaan kapur dan varietas adaptif untuk meningkatkan hasil kedelai di lahan sulfat masam aktual. Berita Biologi, 14(2), 155-161.

Kumar, D.S, D.E, Tony., Kumar, A.P., Kumar, K.A., Rao, D.B.S. \& Nadendla, R. (2013). A review on: Abelmoschus esculentus (okra). International Research Journal of Pharmaceutical and Applied Sciences, 3(4), 129-132.

Lamar, J.E. (1961). Uses of limestone and dolomite. E-book. http://core.ac.uk/down load/pdf/ 10208934.pdf 8 Juni 2019.

Liyanda, M., Karim, A. \& Abubakar, Y. (2012). Analisis kriteria kesesuaian lahan terhadap produksi kakao pada tiga klaster pengembangan di Kabupaten Pidie. Jurnal Agrista, 16(2), 62-79.

Mahendra, D. (2018). Pengaruh Pupuk Kandang dan Pupuk NPK Pada Tanaman Okra (Abelmoschus esculentus L Moench). Doctoral dissertation. http://repository.ub.ac.id/12634/ 7 Mei 2019.

Maryam, A., Susila, A.D. \& Juang Gema Kartika, J.G. (2015). Pengaruh jenis pupuk organik terhadap pertumbuhan dan hasil panen tanaman sayuran di dalam nethouse. Bul. Agrohorti, 3(2), 263-275. DOI: http://dx.doi.org/10.29244/ agrob.3.2.263-275.

Mulyani, A. \& Sarwani, M. (2013). Karakteristik dan potensi lahan sub optimal untuk pengembangan pertanian Indonesia. Indonesian Journal of Land Resources, 7(1),47-55.DOI:http://dx.doi.org/ 10.2018/jsdl.v7i1.6429.

Napitupulu, D \& Winarto, L. (2010). Pengaruh pemberian pupuk $\mathrm{N}$ dan $\mathrm{K}$ terhadap pertumbuhan dan produksi bawang merah. J.Hort, 20(1), 2735.DOI: http://dx.doi.org/10.21082/jhort. v20n1.2010.27-35.

Nariratih, I., Damanik, M.M.B. \& Sitanggang, G.S.G. (2013). Ketersediaan nitrogen pada tiga jenis tanah akibat pemberian tiga bahan organik dan serapannya pada tanaman jagung. Agroekoteknologi, 1(3), 479- 488.

Nurwanto, A. \& Sulistyaningsih, N. (2017). Aplikasi berbagai dosis pupuk kalium dan kompos terhadap produksi tanaman cabai rawit (Capsicum Frutescens L.). Agritrop: Jurnal Ilmu-Ilmu Pertanian: 15(2): 181-193. DOI: http://dx.doi.org/ 10.32528/agr.v15i2.1172.

Prasetyo, B.H. \& Suriadikarta, D.A. (2006). Karakteristik, potensi, dan teknologi pengelolaan tanah ultisol untuk pengembangan pertanian lahan kering di Indonesia. Jurnal Litbang Pertanian, 25(2), 3946 .

Raditya, J., Purbajanti, E.\& Slamet,W. (2017). Pertumbuhan dan produksi okra (Abelmoschus esculentus L.) pada level pemupukan dan jarak tanam yang berbeda. Jurnal Agro Complex, 1 (2), 49-56. DOI: http://10.14710/joac.1.2.49-56.

Rina. D. (2015). Manfaat Unsur N, P dan K bagi Tanaman. BPTP Kalimantan Timur, Badan Litbang Pertanian, Kementerian Pertanian, Samarinda.

Roy, A., Shrivastava, S.L. \& Mandal, S.M. (2014). Functional properties of Okra Abelmoschus esculentus L.(Moench): traditional claims and scientific evidences. Plant Science Today, 1(3), 121-130. DOI: http://10.14719/pst.2014.1.3.63

Saputro, W., Sarwitri, R. \& Ingesti, P.S.V. (2017). Pengaruh dosis pupuk organik dan dolomit pada lahan pasir terhadap pertumbuhan dan hasil 
tanaman kedelai (Glycine max, L.Merrill). VIGOR : Jurnal ilmu Pertanian Tropika dan Subtropika, 2(2), 70-73.

Savci, S. (2012). An agricultural pollutant: chemical fertilizer. International Journal of Environmental Science and Development, 3(1), 77-80.

Sentana, S. (2010). Pupuk organik, peluang dan kendalanya. Yogyakarta, Prosiding Seminar Nasional Teknik Kimia Kejuangan. http://repository. upnyk.ac.id /565/1/25.pdf. 5 Januari 2019.

Simatupang, H., Natta, H. \& Herlina, N. (2012). Studi isolasi dan rendemen lignin dari tandan kosong kelapa Sawit (TKKS). Jurnal Teknik Kimia USU, 1(1), 20-24.

Simbolon, Y., Simanihuruk, B.W., Murcitro, B.G., Gusmara, H. \& Suprijono, E. (2018). Pengaruh subtitusi pupuk $\mathrm{N}$ sintetik dengan limbah lumpur sawit terhadap pertumbuhan dan hasil jagung manis. Jurnal Ilmu-Ilmu Pertanian Indonesia, 20(2), 51-59. DOI: https://doi.org/ 10.31186/jipi.20.2.51-59.

Singh, P., Chauhan, V., Tiwari, B.K., Chauhan, S.S., Simon, S., Bilal, S. \& Abidi, A.B. (2014). An overview on okra (Abelmoschus esculentus) and it's importance as a nutritive vegetable in the world. International Journal of Pharmacy and Biological Sciences, 4(2), 227-233.

Singh, R. (2012). Organic Fertilizers: Types, Production and Environmental Impact. Nova Science Inc., New York.

Sitompul, S.M. \& Guritno, B. (1995). Analisis Pertumbuhan Tanaman. Universitas Gajah Mada Press., Yogyakarta

Sofyan, \& Trinurani, E. (2017). Hasil Analisis Pupuk Organik Padat. Laboratorium Kesuburan Tanah dan Nutrisi Tanaman Universitas Padjajaran, Bandung.

Sudaryono, S., Wijanarko, A. \& S, Suyamto, S. (2015). Efektivitas kombinasi amelioran dan pupuk kandang dalam meningkatkan hasil kedelai pada tanah ultisol. Jurnal Penelitian Pertanian Tanaman Pangan, 30(1), 43-51. DOI: http://dx.doi. org/10.21082/jpptp.v30n1.2011.43-51.

Sujana, I.P. (2015). Pengelolaan tanah ultisol dengan pemberian pembenah organik biochar menuju pertanian berkelanjutan. Jurnal Agrimeta, 5(9),1-69.

Sutanto, R. (2002). Penerapan Pertanian Organik. Kanisius, Yogyakarta.
Syahputra, E., Fauzi, F. \& Razali, R. (2015). Karakteristik sifat kimia sub grup tanah ultisol di beberapa wilayah Sumatera Utara. Agroekoteknologi, 4 (1), 1796-1803.

Syahrizal, L.D., Sahari, P. \& Haryanto, E.T. (2014). Pengaruh dosis pupuk organik dan dolomit terhadap pertumbuhan dan hasil tanaman kacang tanah. Agrosains 16(1), 25-28.

Syaputra, D., Alibasyah, M.R. \& Arabia, T. (2015). Pengaruh kompos dan dolomit terhadap beberapa sifat kimia ultisol dan hasil kedelai (Glycine max L. Merril) pada lahan berteras. Jurnal Manajemen Sumberdaya Lahan, 4(1), 535-542.

Tenaya, I.M.N. (2015). Pengaruh interaksi dan nilai interaksi pada percobaan faktorial (Review). Agrotrop, 5(1), 9-20.

Trivana, L. \& Pradhana, A.Y. (2017). Optimalisasi waktu pengomposan dan kualitas pupuk kandang dari kotoran kambing dan debu sabut kelapa dengan bioaktivator promi dan orgadec. Jurnal Sain Veteriner,35(1), 136-144. DOI: https://doi.org/10.22146/jsv.29301.

Turang, A.C. \& Wowiling, J. (2015). Kegunaan Unsur-unsur Hara bagi Tanaman. Balai Pengkajian Teknologi Pertanian Sulawesi Utara. http:// sulut.litbang.pertanian.go. id/ index.php/ publikasi/ 80-publikasi/ leaflet/ 582 -kegunaan unsur -unsur -hara -bagi-tanaman. 14 Iuni 2019

Wartapa, A., Effendi, Y. \& Sukadi. (2009). Pengaturan jumlah cabang utama dan penjarangan buah terhadap hasil dan mutu buah tomat varietas Kaliurang. Jurnal Ilmu-ilmu Pertanian, 5(2), 150-162.

Yenni, Y. (2012). Ameliorasi tanah sulfat masam potensial untuk budidaya tanaman bawang merah (Allium ascalonicum L.). Jurnal Lahan Suboptimal,1(1), 40-49. DOI: https://doi.org/ 10.33230/JLSO.1.1. 2012.3.

Yuliartini, M. S., Sudewa, K. A., Kartini, L., \& Praing, E. R. (2018). Peningkatan hasil tanaman Okra dengan pemberian pupuk kompos dan NPK. GEMA AGRO, 23(1), 11-17. DOI: http:// dx.doi.org/10.22225/ga.23.1.653.11-17.

Zakariyya, F. (2016). Menimbang Indeks Luas Daun Sebagai Variabel Penting Pertumbuhan Tanaman Kakao. Warta Pusat Penelitian Kopi dan Kakao Indonesia, 28(3), 8-12 